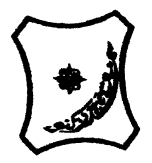

Bayero Journal of Pure and Applied Sciences, 12(1): 117 - 127

ISSN $2006-6996$

\title{
AN ANALYSIS OF AIR POLLUTION AT SOME INDUSTRIAL AREAS OF KANO USING THE AERMOD MODEL
}

\author{
* Maryam Idris ${ }^{1}$, T.H.Darma ${ }^{2}$, F. S. Koki ${ }^{3}$, A. Suleiman ${ }^{4}$, M.H.Ali ${ }^{5}$, S.U.Yarima ${ }^{6}$ and A. Aliyu ${ }^{7}$ \\ 1,2,3,5 Department of Physics, Bayero University, Kano. PMB 3011 Kano State-Nigeria \\ ${ }^{4}$ Department of Civil Engineering, Bayero University, Kano. PMB 3011 Kano State-Nigeria \\ ${ }^{6}$ Nigerian Meteorological Agency (NIMET) Abuja, Nigeria \\ ${ }^{7}$ Department of Physics, Kano University of Science and Technology Wudil \\ midris.phy@buk.edu.ng*, thdarma.phy@buk.edu.ng
}

\section{ABSTRACT}

The effect of pollution on air quality has been a concern for mankind for a long time. In some cases the problem is essentially one of local emissions in a given urban area leading to an adverse effect on air quality in that same area. However, in the general case, the problem is more diverse in that the problem of air pollution has multiplicity effects beyond the point source and these effects are dynamic in nature. Such effects are usually evaluated using dynamical equations. In this study, a comprehensive review on effect of air polluting variables was described on the basis of evaluation of formulation equations of the American Meteorological Society and U.S. Environmental protection Agency Regulatory Model (AERMOD view 9.6.5). The AERMOD model was also used to simulate the dispersion and deposition of the hourly and daily $\mathrm{H}_{2} \mathrm{~S}$ and $\mathrm{NO}_{2}$ concentrations from two domains: Challawa and Sharada industrial estates /areas respectively. The AERMOD model evaluation showed that there was good correlation between the modelled and observed $\mathrm{H}_{2} \mathrm{~S}$ concentration for the daily and hourly comparison at Challawa (0.53 and 0.91 respectively) but the daily and hourly comparison of $\mathrm{H}_{2} \mathrm{~S}$ at Sharada ( 0.13 and 0.46 respectively) was seen to drop indicating poor correlation and model skill. However, model evaluation of $\mathrm{NO}_{2}$ shows poor agreements and model skill at Challawa as well as daily comparison at Sharada. However, the modelling shows good agreement $\left(R^{2}=0.64\right)$ in the trend for the hourly value modelled versus observed concentrations at Sharada. Moreover, the mean absolute percentage error (MAPE) for the two pollutants $\left(\mathrm{H}_{2} \mathrm{~S}\right.$ and $\mathrm{NO}_{2}$ ) at all the two domains indicates highly accurate result for both daily and hourly concentrations. AERMOD software can therefore be used to estimate the dispersion and deposition of the pollutants at some domains considered in this study.

Key Words: AERMOD model, Air pollutant, Industrial sources, Dispersion and Deposition

\section{INTRODUCTION}

The effect of pollution on air quality has been a concern for mankind for a long time. Poor air quality originally resulted primarily from coal burning, both domestic and industrial. (Haynes, 2010). Air pollutants are airborne particles and gasses that occur in concentrations that endanger the health and well-being of organism thus disrupting the orderly function of the environment (Ofoegbu et al., 2014).

In order to have an efficient monitoring of air quality, measuring instrument need to be placed at any location of interest. However, this is not possible even in advanced places. Therefore, scientist suggest the use of air dispersion modelling which estimate the impact of point, line, area and volume sources to surface air quality at any given location (Gibson et al., 2013).

A number of studies have been carried out to evaluate and compare AERMOD'S performance to other air dispersion models. Gibson et al. (2013) showed that AERMOD has shown its utility as a suitable model for conducting dispersion modelling from point and line sources in Nova Scotia with good model skill for estimating annual and monthly $\mathrm{SO}_{2}$ concentration in Halifax and Sydney. The study also highlights the validity of using emission inventory data to estimate the surface impact of major point and line sources within domains containing complex terrain, differing land use types and with large variability within the annual meteorology. Demirarslan et al. (2017) revealed that the highest concentration varied according to the models and time options. This study presents a comprehensive review on effect of air polluting variables which was described on the basis of evaluation of formulation equations of the American Meteorological Society and U.S. Environmental protection Agency Regulatory Model (AERMOD view 9.6.5). 
Special Conference Edition, November, 2019

The AERMOD model was also used to simulate the dispersion and deposition of the hourly and daily $\left(\mathrm{H}_{2} \mathrm{~S}\right.$ and $\left.\mathrm{NO}_{2}\right)$ concentrations from three domains: Challawa and Sharada industrial estates /areas respectively.

\section{MATERIALS AND METHODS}

The methodology of this work comprises of a comprehensive review on the basis of evaluation of formulation equations of the AERMOD model and simulation of the characteristics of the hourly and daily concentrations of $\mathrm{NO}_{2}$ and $\mathrm{H}_{2} \mathrm{~S}$ by the use of AERMOD model.

\section{Sampling}

Three industrial estate/ areas were considered from the four industrial estate /areas situated in Kano sate- Nigeria. The air samples were collected at three different stages from the point source and this was repeated twelve times at an interval of $1 \mathrm{hr}$ from the starting time. The Gasman operating Instrument (Crowcon detection instrument Itd) obtained from the Ministry of Environment (Pollution control department), Kano was used to detect the concentration of the air polluting agents and the AERMOD software was used to predicts the dispersion and deposition of pollutants considered in this study. The pollutants that were detected are; $\mathrm{H}_{2} \mathrm{~S}$ and $\mathrm{NO}_{2}$. The sampling was conducted between the months of JanuaryApril, 2018.

\section{Study Area}

Kano is the state capital of Kano state in North West, Nigeria. It is situated in the sahelian geographic region, south of the Sahara. Kano is the commercial nerve Centre of Northern Nigeria and is the second largest city in Nigeria, after Lagos. Kano is located between latitude $11^{\circ} 20^{\prime \prime} N$ to $125^{\prime} 40^{\prime \prime} N$ of the equator and longitude $8{ }^{\circ} 4^{\prime} 30^{\prime \prime} E$ to $8^{\circ} 43^{\prime} 40^{\prime \prime} E$ of the prime meridian. Samples were collected from some manufacturing industries at the three industrial zones situated in Kano state Nigeria which includes: Chalawa and Sharada industrial estate/area. The study area in Figure 2 shows the three industrial estate/ areas.

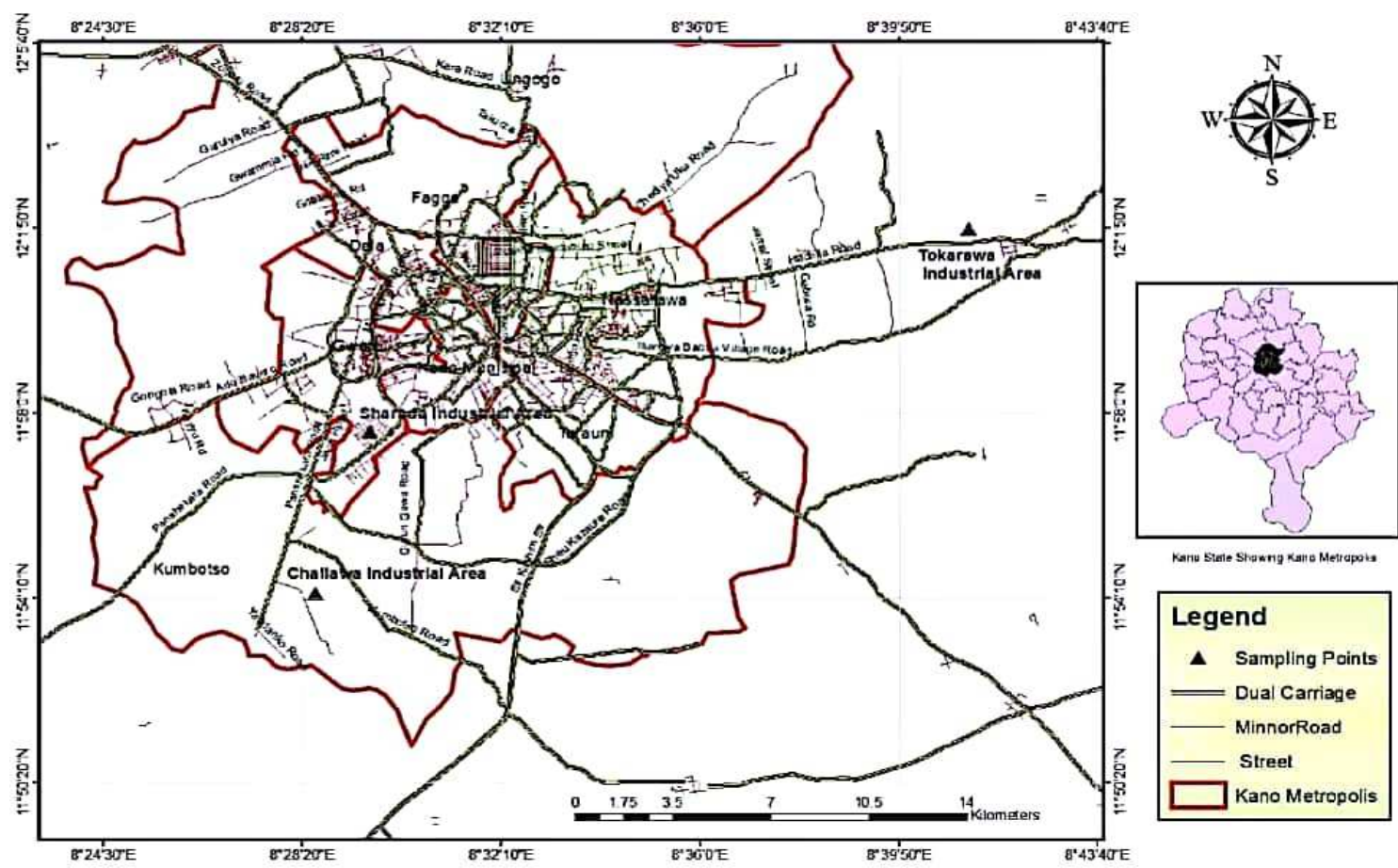

Figure 1: Study area of the three industrial estate /areas in Kano state -Nigeria (Department of Geography, 2019)

Stack Characteristics And Input Data For Dispersion Model

Table 1 and 2 shows the input data used for the dispersion model and stack characteristics respectively. 
Special Conference Edition, November, 2019

Table 1. Input data use for the dispersion model

Input Data

Land use type

Grassland

Source data

Terrain coefficient

Distribution coefficient

Time option

Receptors

Grid size

Surface roughness length

Albedo

Point sources

Flat

Urban

Bowen rate

Hourly(1 hr) and Daily (24hr)

441 uniform Cartesian $(21 \times 21)$

$1000 \mathrm{~m} \times 1000 \mathrm{~m}$

0.05

0.18

0.4

Table 2: Challawa, Sharada and Tokarawa Industrial Estate/area Stack characteristics

\begin{tabular}{|c|c|c|c|c|c|c|c|c|}
\hline Domain & $\begin{array}{l}\text { Stack } \\
\text { location }\end{array}$ & $\begin{array}{l}\text { Stack } \\
\text { xteristic }\end{array}$ & $\begin{array}{l}\text { UTM } \\
(X: Y) \\
(\mathbf{m})\end{array}$ & $\begin{array}{l}\text { RH } \\
\text { (m) }\end{array}$ & $\begin{array}{l}\mathrm{EV} \\
(\mathrm{m} / \mathrm{s})\end{array}$ & $\begin{array}{l}\text { ET } \\
(\boldsymbol{K})\end{array}$ & $\begin{array}{l}\mathrm{NO}_{2} \\
\mathrm{ER}(\mathrm{g} / \mathrm{s})\end{array}$ & $\begin{array}{l}\mathrm{H}_{2} \mathrm{~S} \\
\mathrm{ER}(\mathrm{g} / \mathrm{s})\end{array}$ \\
\hline \multirow[t]{2}{*}{1} & $\begin{array}{l}\text { Fata Tanning } \\
\text { ind. }\end{array}$ & Point source & $\begin{array}{l}442317.13: \\
1316095.52\end{array}$ & 21 & 10 & 311.7 & 0.507247 & 0.299324 \\
\hline & $\begin{array}{l}\text { Mamuda } \\
\text { Tanning Ind. }\end{array}$ & Point source & $\begin{array}{l}442644.37: 13 \\
15765.13\end{array}$ & 18 & 11.32 & 316.2 & 0.944193 & 1.813704 \\
\hline \multirow[t]{2}{*}{2} & $\begin{array}{l}\text { S. Roda \& } \\
\text { Sons/M.C } \\
\text { Plastic }\end{array}$ & Point source & $\begin{array}{l}447306.31: 13 \\
23142.11\end{array}$ & 16 & 13.2 & 308.3 & 0.504941 & 0.592 \\
\hline & Geepee Plastic & Point source & $\begin{array}{l}447054.17: 13 \\
23050.44\end{array}$ & 16 & 1.49 & 307.8 & 0.000214 & 0.000387 \\
\hline \multirow[t]{2}{*}{3} & $\begin{array}{l}\text { Viva polybag } \\
\text { ind. }\end{array}$ & Point source & $\begin{array}{l}466346.02: 13 \\
29676.17\end{array}$ & 21 & 13.2 & 313.8 & 0.533395 & 0.855126 \\
\hline & $\begin{array}{l}\text { Asian/Standard } \\
\text { footwear ind. }\end{array}$ & Point source & $\begin{array}{l}467158.93: 13 \\
30220.17\end{array}$ & 30 & 20.23 & 314.6 & 0.726639 & 1.180788 \\
\hline
\end{tabular}

Key: 1 = Challawa ind. Est., 2 = Sharada ind. Est, 3 = Tokarawa ind. Est, RH = Release Height, EV = Exit Velocity, ET = Exit Temp

\section{Meteorological Observations}

Hourly surface air data such as: temperature, cloud cover, wind speed, wind direction, air pressure, relative humidity and precipitation measurement were obtained from Malam Aminu Kano international Airport. The data were used for the model simulation for all the three domains. The upper air data was estimated from the hourly surface data by the use of upper air estimator in the model.

\section{Statistical Methods}

In order to evaluate the model, two different statistical methods were used to compare the measured and predicted values.

$$
N M S E=\frac{\left.\left(\overline{C_{\circ}}-\overline{C_{P}}\right)\right)^{2}}{\overline{C_{0} \times \overline{C_{P}}}}
$$

The Normalised Mean Squared Error (NMSE) method presented in equation (1) was used as the first method were $C_{0}$ is the measured (observed) concentration value, and $C_{p}$ is the predicted concentration value. A result less than 0.5 implies that the measured and modelled results are comparable (Demirarslan et al., 2017). The result of these calculations are dimensionless (Ozkurt et al., 2013).

$$
\text { MAPE }=\frac{\sum \frac{\left|Y_{t}-F_{t}\right|}{Y_{t}}}{n}
$$


Special Conference Edition, November, 2019 where $\mathrm{t}$ is the time period, $\mathrm{n}$ is the number of periods forecast, $Y_{t}$ is the actual or observed concentration in time period $\mathrm{t}$ and $F_{t}$ is the predicted concentration in time period $t$. The Mean Absolute Percentage Error (MAPE) presented in equation (2) was the second method, which does attempt to consider the effect of the magnitude of the actual values. The lower the MAPE the more accurate the forecast. Scale to judge the accuracy of a model based on the MAPE measurements includes: Less than $10 \%$ is highly accurate, $11 \%$ to $20 \%$ shows good forecast, $21 \%$ to $50 \%$ indicates reasonable forecast, $51 \%$ or more is inaccurate forecast (Lawrence et al., 2009).

\section{Model Description}

The American Meteorological Society and U.S. Environmental protection Agency Regulatory Model (AERMOD) is a steady-state Gaussian plume dispersion model aimed at short-range distance $(<50 \mathrm{~km})$.It is a commonly used regulatory air pollution dispersion model that can be applied to many different sources, including point, line, area, and volume sources ( Cimorelli et al.,2003;Perry et al.,1994). One of the major improvements that AERMOD brings to applied dispersion modelling is its ability to characterize the planetary boundary layer (PBL) through both surface and mixed layer scaling which serve as a younger generation of the ISCST-3 (Demirarslan et al.,2017). AERMOD (Lakes Environmental, Ontario,Canada) incorporates meteorological data pre-processing (AERMET) and use modern knowledge on planetary boundary layer theory, which serve as a replacement to pasquill-Gifford stability classbased plume dispersion models such as ISCST3, and ISC-PRIME by the USEPA(Gibson et al.,2013).

Figure 1 shows the flow and processing of information in AERMOD. The modelling system consists of one main program (AERMOD) and two pre-processors (AERMET and AERMAP). The major purpose of AERMET is to calculate boundary layer parameters for use by AERMOD. The meteorological INTERFACE, internal to $A E R M O D$, uses these parameters to generate profiles of the needed meteorological variables. In addition, AERMET passes all meteorological observations to AERMOD.

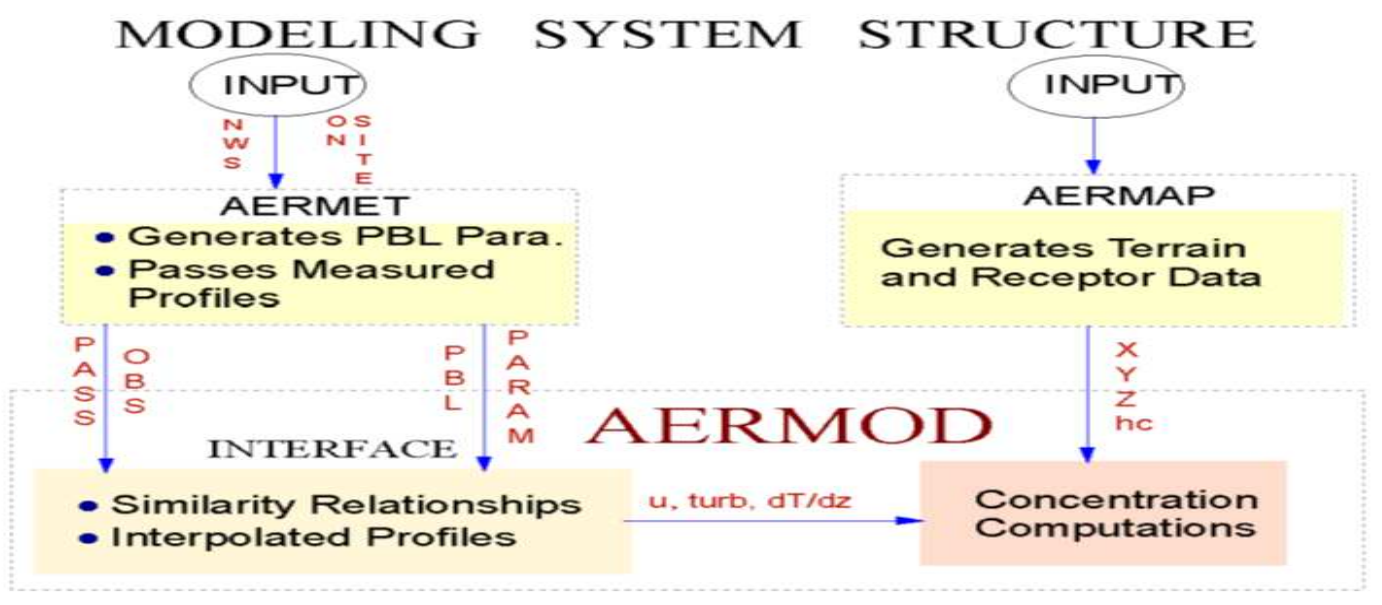

Figure 2: Data flow in the AERMOD modelling system (Lakes environmental, 2018)

The AERMIC terrain pre-processor AERMAP uses gridded terrain data to calculate a representative terrain-influence height $\left(h_{c}\right)$, also referred to as the terrain height scale. The terrain height scale $h_{c}$, which is uniquely defined for each receptor location, is used to calculate the dividing streamline height. The gridded data needed by AERMAP is selected from Digital Elevation Model (DEM) data. AERMAP is also used to create receptor grids. The elevation for each specified receptor is automatically assigned through AERMAP. For each receptor, AERMAP passes the following information to AERMOD: the receptor's location $\left(x_{r}, y_{r}\right)$, its height above mean sea level $\left(z_{p}\right)$, and the receptor specific terrain height scale $\left(h_{c}\right)$.

Meteorological Pre-Processor (AERMET)

The basic purpose of AERMET is to use meteorological measurements, representative of the modelling domain, to compute certain boundary layer parameters used to estimate profiles of wind, turbulence and temperature. Surface characteristics in the form of albedo, surface roughness and Bowen ratio, plus standard meteorological observations (wind speed, wind direction, temperature, and cloud cover), are input to AERMET. 
Special Conference Edition, November, 2019

Vertical Structure of the PBL - AERMOD'S Meteorological Interface

The AERMOD interface uses similarity relationships with the boundary layer parameters, the measured meteorological data, and other site-specific information provided by AERMET to compute vertical profiles of: (1) wind direction, (2) wind speed, (3) temperature, (4)

$$
\begin{gathered}
u=\left\{7 z_{o}\right\}\left[\frac{z}{7 z_{o}}\right] \\
u=\frac{u_{*}}{k}\left[\operatorname{In}\left(\frac{z}{z_{o}}\right)-\Psi_{m}\left\{\frac{z}{L}\right\}+\Psi_{m}\left\{\frac{z_{o}}{L}\right\}\right] \\
u=u\left\{z_{o}\right\}
\end{gathered}
$$

Where $7 Z$ orepresents an approximate height of roughness elements below which the profile is assumed to be linear. Wind direction is assumed to be constant with height both above the highest and below the lowest measurement and to vary linearly between measurements (Cimorelli et al., 2004).

(b) Potential Temperature Gradient

Above the relatively shallow super adiabatic surface layer, the potential temperature gradient

$$
\begin{array}{lll} 
& \frac{\partial \theta}{\partial z}=\frac{\theta_{*}}{k(2)}\left[1+5 \frac{(2)}{L}\right] & \text { for } Z \leq 2 m \\
\text { and } & & \\
& \frac{\partial \theta}{\partial z}=\frac{\theta_{*}}{k z}\left[1+5 \frac{z}{L}\right] & \text { for } 2 m<z \leq 100 m
\end{array}
$$

Above $100 \mathrm{~m}$ the potential temperature gradient is taken from Stull (1983) and Holtslag and van Ulden (1983) as

$$
\frac{\partial \theta}{\partial z}=\frac{d \theta\left\{z_{m x}\right\}}{d z} \exp \left[-\frac{\left(z-z_{m x}\right)}{0.44 z_{i \theta}}\right]
$$

where $\mathrm{z}_{\mathrm{mx}}=100 \mathrm{~m}, \mathrm{z}_{\mathrm{i} \theta}=\max \left[\mathrm{z}_{\mathrm{im}} ; 100 \mathrm{~m}\right]$ and the constant 0.44 is taken from measurements (Andre \& Mahrt, 1982). For all z, $\partial \theta / \partial z$ is limited to a minimum of $0.002 \mathrm{Km}^{-1}$ (Paine \& Kendall, 1993).

\section{(c) Vertical Turbulence}

In the $\mathrm{CBL}$, the vertical velocity variance or turbulence $\left(\sigma_{w}^{2}\right)$ is profiled using an expression based on a mechanical or neutral stability limit $\left(\left(\sigma_{w m} \propto u^{*}\right)\right.$ and a strongly convective limit $\left(\left(\sigma_{w m} \propto w^{*}\right)\right.$. The total vertical turbulence is given by:

$$
\theta\{z+\Delta z\}=\theta\{z\}+\left.\frac{\partial \theta}{\partial z}\right|_{\bar{z}} \Delta z
$$

The convective portion ( $\sigma 2 w c$ ) of the total variance is calculated as:

and

$$
\begin{array}{cc}
\sigma_{w c}^{2}=1.6\left(\frac{z}{z_{i c}}\right)^{\frac{2}{3}} \cdot w_{*}^{2} & \text { for } z \leq 0.1 z_{i c} \\
\sigma_{w c}^{2}=0.35 w_{*}^{2} & \text { for } 0.1 z_{i c}<z \leq z_{i c}
\end{array}
$$

$$
\sigma_{w c}^{2}=0.35 w_{*}^{2} \exp \left[-\frac{6\left(z-z_{i c}\right)}{z_{i c}}\right] \quad \text { for } z>z_{i c}
$$

where the expression for $0.1 z_{i c}<z \leq z_{i c}$ is the free convection limit (Panofsky et al., 1977), $0.1 z_{i c}<$ $z \leq z_{i c}$ is the mixed-layer value (Hicks, 1985), and for $z>z_{i c}$ is a parameterization to connect the mixed layer to the assumed near-zero value well above the CBL

The mechanical turbulence $\left(\sigma_{w m}\right)$ is assumed to consist of a contribution from the boundary layer $\left(\sigma_{w m l}\right)$ and from a "residual layer" $\left(\sigma_{w m r}\right)$ above the boundary layer $\left.\left(z>z_{i}\right)\right)$ such that;

$$
\sigma_{w m}^{2}=\sigma_{w m l}^{2}+\sigma_{w m r}^{2}
$$

This is done to satisfy the assumed decoupling between the turbulence aloft $\left(z>z_{i c}\right)$ and that at the surface in the CBL shear layer, and to maintain a continuous variation of $\sigma_{w m}^{2}$ with z near $z=z_{i}$.

$$
\begin{array}{cc}
\sigma_{w m l}=1.3 u_{*}\left(1-\frac{z}{z_{i}}\right)^{\frac{1}{2}} & \text { for } z<z_{i} \\
\sigma_{w m l}=0.0 & \text { for } z \geq z_{i}
\end{array}
$$


Special Conference Edition, November, 2019 where the $\sigma_{w m l}=1.3 u_{*}$ at $z=0$ is consistent with Panofsky et al. (1977).

If measurements are not available, then $\sigma_{w m r}$ is taken as the default value of $0.02 u\left\{z_{i}\right\}$. The constant 0.02 is an assumed turbulence intensity $i_{z} \quad\left(=\left(\sigma_{w m} / u\right)\right)$ for the very stable conditions presumed to exist above $z_{i}$ (Briggs, 1973).

\section{(d) Lateral Turbulence}

In the CBL the total lateral turbulence is also assumed to be a combination of a mechanical $\left(\sigma_{v m}\right)$ and convective $\left(\sigma_{v c}\right)$ portions such that

$$
\sigma_{v T}^{2}=\sigma_{v c}^{2}+\sigma_{v m}^{2}
$$

In the SBL the total lateral turbulence contains only a mechanical portion. AERMOD, uses the same $\sigma_{v m}$ expression in the CBL and SBL. This is done to maintain continuity of $\sigma_{v m}$ in the limit of neutral stability.

Panofsky and Dutton (1984) report that, in purely mechanical turbulence, the lateral variance near the surface has the form:

$$
\sigma_{v o}^{2}=C u_{*}^{2}
$$

where the constant, C, ranges between 3 and 5 . Based on an analysis of the Kansas data, Izumi (1971) and Hicks (1985) support the form of eq. (36) with a value of 3.6 for $C$.

Between the surface and the top of the mechanically mixed layer, $\sigma_{v m}^{2}$ is assumed to vary linearly as $5 \mathrm{fr}$

$$
\begin{array}{r}
\sigma_{v m}^{2}=\left[\frac{\sigma_{v m}^{2}\left\{z_{i m}\right\}-\sigma_{v o}^{2}}{z_{i m}}\right] z+\sigma_{v o}^{2} \\
\text { for } z \leq z_{i m} \quad \sigma_{v m}^{2}=\sigma_{v m}^{2}\left\{z_{i m}\right\} \\
\text { for } z>z_{i m}, \quad(33)
\end{array}
$$

where $\sigma_{v m}^{2}\left\{z_{i m}\right\}=\min \left[\sigma_{v o}^{2} ; 0.25 m^{2} s^{-2}\right]$ and $\sigma_{v o \text {, }}^{2}$ the surface value of the lateral turbulence, is equal to $3.6 u_{*}^{2}$. This linear variation of $\sigma_{v m}^{2}$ with $z$ is consistent with field observations (e.g., Brost et al. (1982).

The convective portion of the lateral turbulence within the mixed layer is constant and calculated as:

$$
\sigma_{v c}^{2}=0.35 w_{*}^{2} \text {, }
$$

which is supported by the Minnesota data (Readings et al. 1974; Kaimal et al. 1976) and by data collected at Ashchurch England (Caughey \& Palmer 1979).

\section{General Structure of AERMOD Including Terrain}

In general, AERMOD models a plume as a combination of two limiting cases: a horizontal plume (terrain impacting) and a terrain-following plume. Therefore, for all situations, the total concentration, at a receptor, is bounded by the concentration predictions from these states. In flat terrain the two states are equivalent. By incorporating the concept of the dividing streamline height, in elevated terrain, AERMOD's total concentration is calculated as a weighted sum of the concentrations associated with these two limiting cases or plume states (Venkatram et al., 2001).

The general concentration equation, which applies in stable or convective conditions is given by

$$
\begin{aligned}
C_{T}\left\{X_{r}, Y_{r}, Z_{r}\right\}= & f . C_{c, s}\left\{X_{r}, Y_{r}, Z_{r}\right\} \\
& +(1 \\
& -f) C_{c, s}\left\{X_{r}, Y_{r}, Z_{p}\right\}
\end{aligned}
$$

where $C_{T}\left\{X_{r}, Y_{r} Z_{r}\right\}$ is the total concentration, $C_{c, s}\left\{Z_{r}, Y_{r}, Z^{r}\right\}$ is the contribution from the horizontal plume state. (Subscripts $c$ and $s$ refer to convective and stable conditions, respectively), $C_{c, s}\left\{Z_{r}, Y_{r}, Z^{r}\right\}$ is the contribution from terrain-following state, $f$ is the plume state weighting function, $\left\{X_{r}, Y_{r}, Z_{r}\right\}$ is the coordinate representation of a receptor (with $Z_{r}$ defined relative to stack base elevation) $Z_{r}=Z_{r}-Z_{t}$ is the height of a receptor above local ground, and $Z_{r}$ is the terrain height at a receptor. Note that in flat terrain, $Z_{t}=0, Z_{p}=Z_{r}$ and the concentration (eq. (35) reduces to the form for a single horizontal plume. It is important to note that for any concentration calculation all heights ( $z$ ) are referenced to stack base elevation. Figure 3, ilustrates the relationship between the actual plume and AERMOD's characterization of it. 


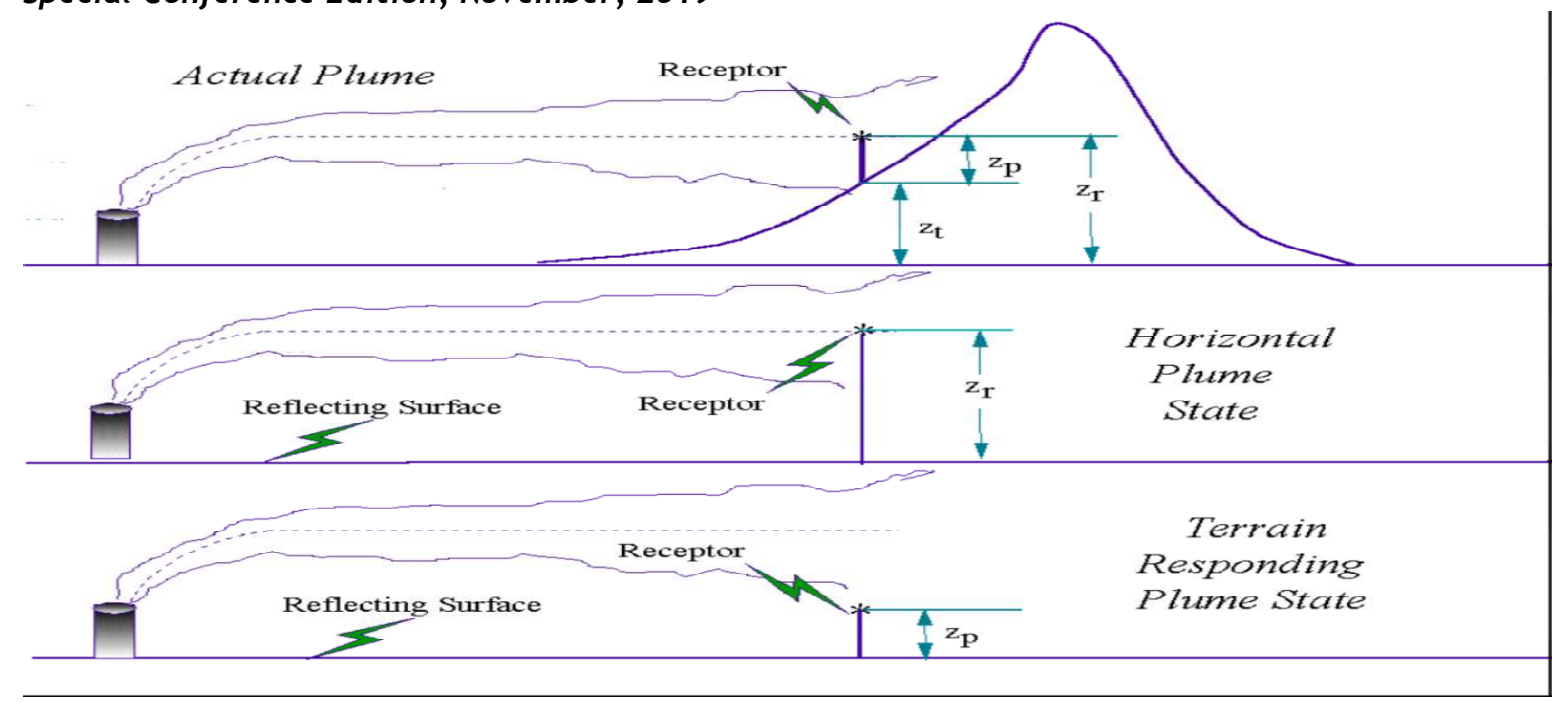

Figure 3: AERMOD two state approach. The total concentration predicted by AERMOD is the weighted sum of the two extreme possible plume states (Lakes Environmental, 2018).

The formulation of the weighting factor requires the computation of $H_{c}$. Using the receptor specific terrain height scale $h_{c}$ from AERMAP, $H_{c}$ is calculated from the same algorithms found in CTDMPLUS as:

$$
\frac{1}{2} \cdot U^{2}\left\{H_{c}\right\}=\int_{H_{c}}^{h_{c}} N^{2}\left(h_{c}-z\right) d z
$$

Where $u\left\{H_{c}\right\}$ is the wind speed at height $H_{c}$, and $\mathrm{N}=\left[\frac{g}{\theta} \frac{\partial \theta}{\partial z}\right] 1 / 2$ is the Brunt-Vaisala frequency. The height scale, $h_{c}$ characterizes the height of the surrounding terrain that most dominates the flow in the vicinity of the receptor.

(a) Concentration Predictions in the Convective Boundary Layer (CBL)

In AERMOD, the dispersion formulation for the convective boundary layer $(\mathrm{CBL})$ represents one of the more significant model advances by comparison with existing regulatory models. In AERMOD, the total concentration $\left(C_{c}\right)$ in the $\mathrm{CBL}$ is found by summing the contribution from the three sources. For the horizontal plume state, the $C_{c}$ is given by

$$
C_{c}\left\{X_{r}, Y_{r}, Z_{r}\right\}=C_{d}\left\{X_{r}, Y_{r}, Z_{r}\right\}+C_{r}\left\{X_{r}, Y_{r}, Z_{r}\right\}+C_{p}\left\{X_{r}, Y_{r}, Z_{r}\right\}
$$

Where $C_{d}, C_{r}$ and $C_{p}$ are the contributions from the direct, indirect and penetrated sources, respectively. The total concentration for the terrain-following state has the form of eq. (37) but with $z_{r}$ replaced by $z_{p}$.

(b) Concentration Predictions in the Stable Boundary Later (SBL)

For stable conditions, the AERMOD concentration expression (Cs in eq. (35) has the Gaussian form, and is similar to that used in many other steady-state plume models (e.g., HPDM (Hanna \& Paine 1989)). The Cs is given by

$$
C_{s}\left\{x_{r}, y_{r}, z\right\}=\frac{Q\left(1-f_{p}\right)}{\sqrt{2 \pi} \tilde{u} \sigma_{z s}} F_{y} \cdot \sum_{m=-\infty}^{\infty}\left[\exp \left(-\frac{\left(z-h_{e s}+2 m z_{\text {ieff }}\right.}{2 \sigma_{z s}^{2}}\right)^{2}+\exp \left(-\frac{\left(z-h_{e s}+2 m z_{i e f f}\right)^{2}}{2 \sigma_{z s}^{2}}\right)^{2}\right],
$$

where $Z_{\text {ieff }}$ is the effective mechanical mixed layer height, $\left(\sigma_{z p}\right)$ is the total vertical dispersion in the $\mathrm{SBL}$ and $h_{e s}$ is the plume height (i.e., stack height plus the plume rise).

\section{RESULTS AND DISCUSSION}

Equation (1) and (2) were used to evaluate the model performance by comparing the measured results and the modelled results. Tables 3, 4 and 5 contains the results of the AERMOD simulation of the three domains which includes the daily and hourly AERMOD estimated and observed concentrations for each parameter at the discrete receptors within each domain. 
Special Conference Edition, November, 2019 Challawa Domain

From figure $4 a$ and $4 b$, it can be seen that the highest hourly predicted $\mathrm{H}_{2} \mathrm{~S}$ concentration $\left(1036.43 \mu \mathrm{g} \mathrm{m}^{-3}\right)$ was found directly to the south of stack 1 followed by stack $2\left(681.69 \mu \mathrm{g} \mathrm{m}^{-3}\right)$. However, it was observed that the daily predicted $\mathrm{H}_{2} \mathrm{~S}$ concentration from all the stacks was far below the hourly predicted concentration with stack $2\left(266.99 \mu \mathrm{g} \mathrm{m}^{-3}\right)$ recording the highest. The reason for the hourly increase concentration gradient was as a result of the North-East prevailing wind that is advecting the point source to the south west of their sources.
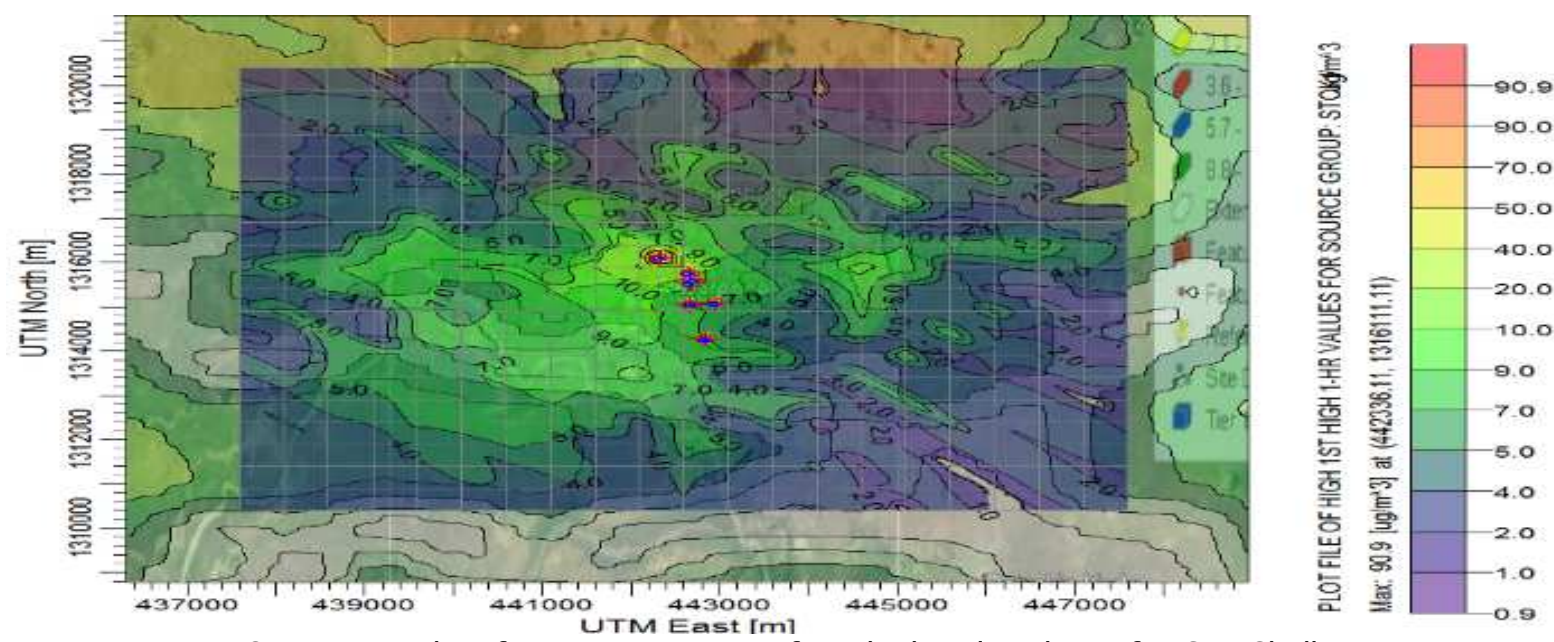

Figure 4a. AERMOD estimated surface concentration of stack1 hourly values of $\mathrm{H}_{2} \mathrm{~S}$ in Challawa domain
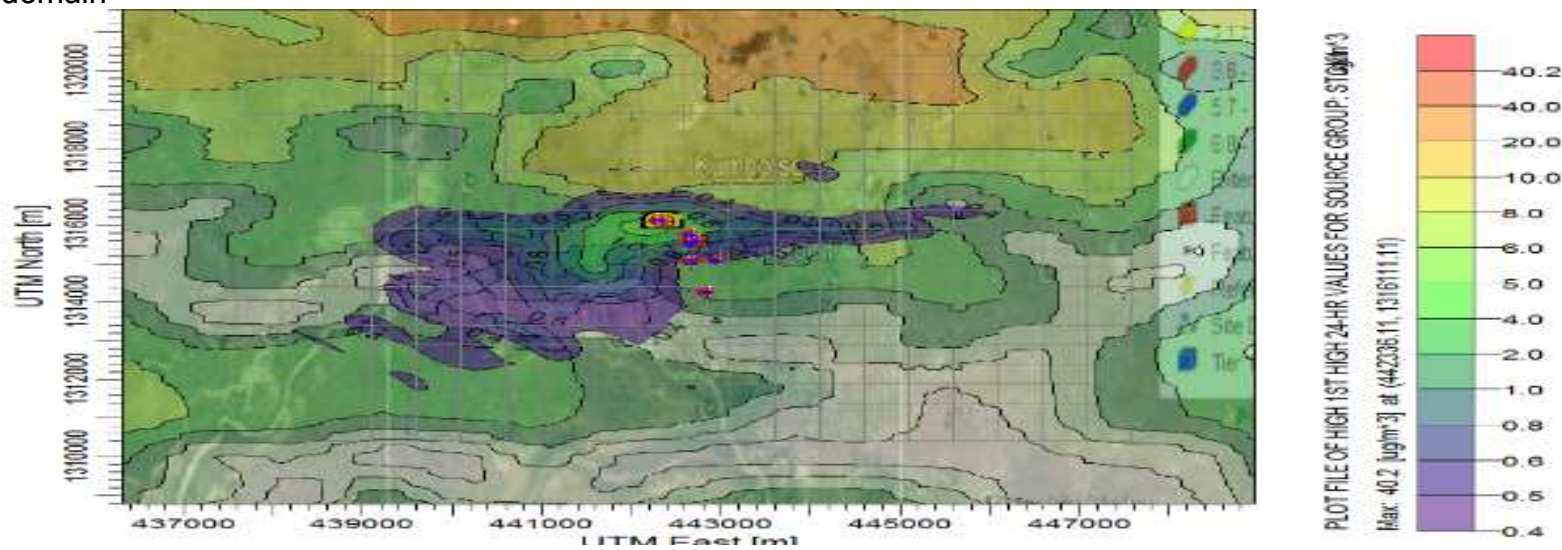

Figure 4b. AERMOD estimated surface concentration of stack1 daily values of $\mathrm{H}_{2} \mathrm{~S}$ in Challawa domain.

Table 3. The statistical result of the AERMOD simulation for Challawa domains

\begin{tabular}{|c|c|c|c|c|c|c|}
\hline $\begin{array}{l}\text { Model } \\
\text { domain }\end{array}$ & Parameters & $\begin{array}{l}\text { Modelled } \\
\text { daily and } \\
\text { hourly } \\
\text { averages } \\
\left(\mu \mathrm{gm}^{-3}\right)\end{array}$ & $\begin{array}{l}\text { Observed } \\
\text { daily and } \\
\text { hourly } \\
\text { averages } \\
\left(\mu \mathrm{gm}^{-3}\right)\end{array}$ & $\begin{array}{l}\text { Modelled } v \\
\text { observed } R^{2} \\
\text { daily and } \\
\text { hourly }\end{array}$ & $\begin{array}{l}\text { Daily NMSE } \\
\text { Hourly } \\
\text { NMSE }\end{array}$ & $\begin{array}{l}\text { Daily MAPE } \\
\text { Hourly } \\
\text { MAPE }\end{array}$ \\
\hline \multirow[t]{2}{*}{ Challawa } & $\mathrm{H}_{2} \mathrm{~S}$ & $\begin{array}{l}278.00 \\
1036.00\end{array}$ & $\begin{array}{l}305.25 \\
543.29\end{array}$ & $\begin{array}{l}0.53 \\
0.91\end{array}$ & $\begin{array}{l}27.20 \\
12.40\end{array}$ & $\begin{array}{l}0.07 \\
0.08\end{array}$ \\
\hline & $\mathrm{NO}_{2}$ & $\begin{array}{l}144.00 \\
1984.00\end{array}$ & $\begin{array}{l}406.14 \\
444.28\end{array}$ & $\begin{array}{l}0.01 \\
0.05\end{array}$ & $\begin{array}{l}0.79 \\
2.70\end{array}$ & $\begin{array}{l}0.05 \\
0.29\end{array}$ \\
\hline
\end{tabular}


Special Conference Edition, November, 2019

The AERMOD estimated and observed concentrations for $\mathrm{H}_{2} \mathrm{~S}$ at the discrete receptors was shown in table 3 . The $R^{2}(0.53)$ for the modelled versus observed daily and hourly (0.91) concentration were in good agreement with the modelled. The daily and hourly NMSE was found to be 27.20 and 12.40 respectively which is far from perfect model $(\mathrm{NMSE}=1)$. The MAPE result for daily and hourly $\mathrm{H}_{2} \mathrm{~S}$ concentration shows highly accurate result for the modelled versus observed comparison.

The $\mathrm{R}^{2}$ for the modelled versus observed daily and hourly $\mathrm{NO}_{2}$ concentrations were characterised by extremely weak correlation between the daily and hourly result $\left(R^{2}=0.01\right.$ and 0.05 respectively). The NMSE result for daily and hourly comparison are poor and far from perfect model except for the daily NMSE result which approaches 1 showing good model skill for $\mathrm{NO}_{2}$ in challawa domain. The daily MAPE showed highly accurate result while the hourly MAPE result for the observed versus modelled showed reasonable forecast accuracy.

\section{Sharada Domain}

The hourly and daily averaging concentrations of $\mathrm{H}_{2} \mathrm{~S}$ and $\mathrm{NO}_{2}$ in Sharada domain are presented table 4.

Table 4. The statistical result of the AERMOD simulation for Sharada domains

\begin{tabular}{|c|c|c|c|c|c|c|}
\hline $\begin{array}{l}\text { Model } \\
\text { domain }\end{array}$ & $\begin{array}{l}\text { Parameter } \\
\text { s }\end{array}$ & $\begin{array}{l}\text { Modelled } \\
\text { daily and } \\
\text { hourly } \\
\text { averages } \\
\left(\mu \mathrm{gm}^{-3}\right)\end{array}$ & $\begin{array}{l}\text { Observed } \\
\text { daily and } \\
\text { hourly } \\
\text { averages } \\
\left(\mu \mathrm{gm}^{-3}\right)\end{array}$ & $\begin{array}{l}\text { Modelled } v \\
\text { observed } \\
R^{2} \text { daily } \\
\text { and hourly }\end{array}$ & $\begin{array}{l}\text { Daily } \\
\text { NMSE } \\
\text { Hourly } \\
\text { NMSE }\end{array}$ & $\begin{array}{l}\text { Daily } \\
\text { MAPE } \\
\text { Hourly } \\
\text { MAPE }\end{array}$ \\
\hline \multirow[t]{2}{*}{ Sharada } & $\mathrm{H}_{2} \mathrm{~S}$ & $\begin{array}{l}176.32 \\
1125.41\end{array}$ & $\begin{array}{l}422.75 \\
714.29\end{array}$ & $\begin{array}{l}0.13 \\
0.46\end{array}$ & $\begin{array}{l}0.82 \\
0.21\end{array}$ & $\begin{array}{l}0.05 \\
0.05\end{array}$ \\
\hline & $\mathrm{NO}_{2}$ & $\begin{array}{l}954.46 \\
1234.61\end{array}$ & \begin{tabular}{|l|}
275.29 \\
714.29
\end{tabular} & $\begin{array}{l}0.06 \\
0.64\end{array}$ & $\begin{array}{l}1.76 \\
0.31\end{array}$ & $\begin{array}{l}0.20 \\
0.06\end{array}$ \\
\hline
\end{tabular}

The AERMOD estimated and observed concentrations for $\mathrm{H}_{2} \mathrm{~S}$ at the discrete receptors was shown in table 4 for the sharada domain. The $R^{2}(0.13)$ for the modelled versus observed daily concentration is characterised by poor correlation while the $R^{2}(0.46)$ for the modelled vesus observed hourly concentration is nearly in good agreement with the modelled. The daily and hourly NMSE was found to be 0.82 and 0.21 respectively which is far better than that of challawa and Tokarawa domain. However, the daily and hourly MAPE was found to be 0.05 and 0.05 respectively which shows highly accurate forecast.
Table 4 contain the estimated AERMOD result for the $\mathrm{NO}_{2}$ concentration. There was good agreement $\left(R^{2}=0.64\right)$ in the trend in the hourly value modelled versus observed concentrations, but there was no correlation observed between the daily comparison $\left(R^{2}=0.06\right)$. The reason for the poor correlation was likely due to AERMOD only calculating a small percentage of the total $\mathrm{NO}_{2}$ emission in Sharada domain. However, the NMSE for the daily result is characterised with poor correlation. Moreover, the NMSE for the hourly comparison result shows good model skill for $\mathrm{NO}_{2}$ in Sharada domain. Figure $5 \mathrm{a}$ and $5 \mathrm{~b}$ shows the highest hourly and daily concentration of $\mathrm{NO}_{2}$ from stack 1 at Sharada domain.
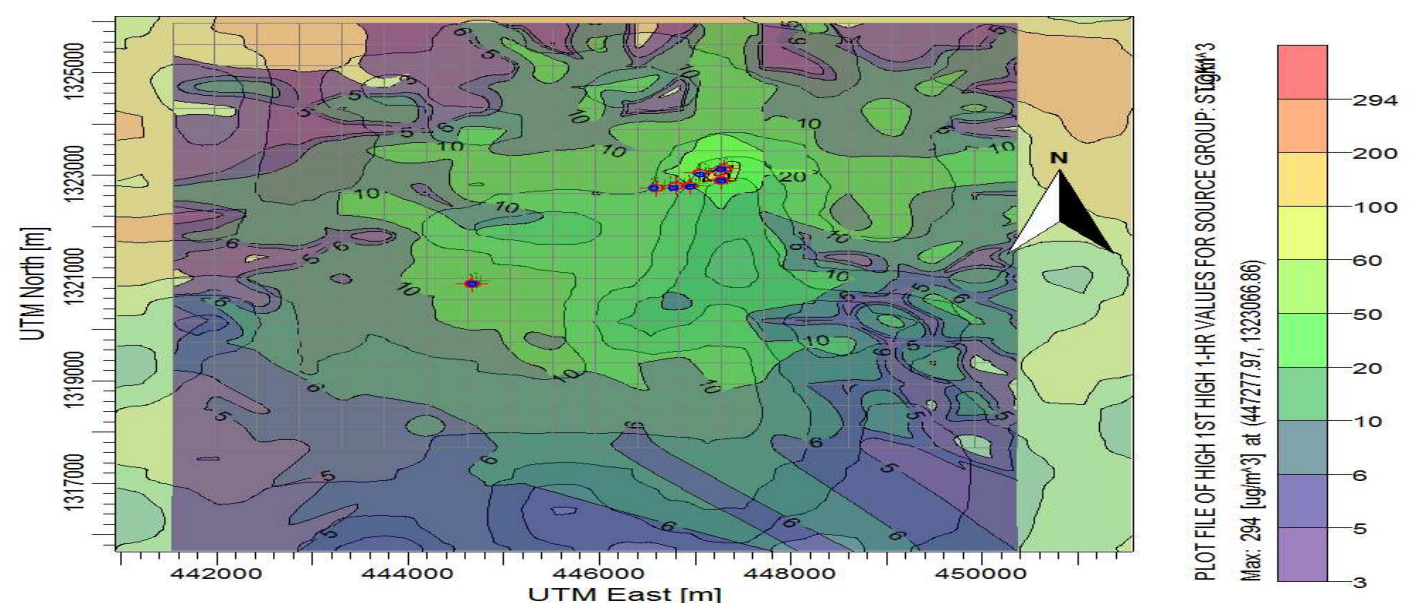

Figure 5a. AERMOD estimated surface concentration of stack 1 hourly values of $\mathrm{NO}_{2}$ in Sharada domain. 


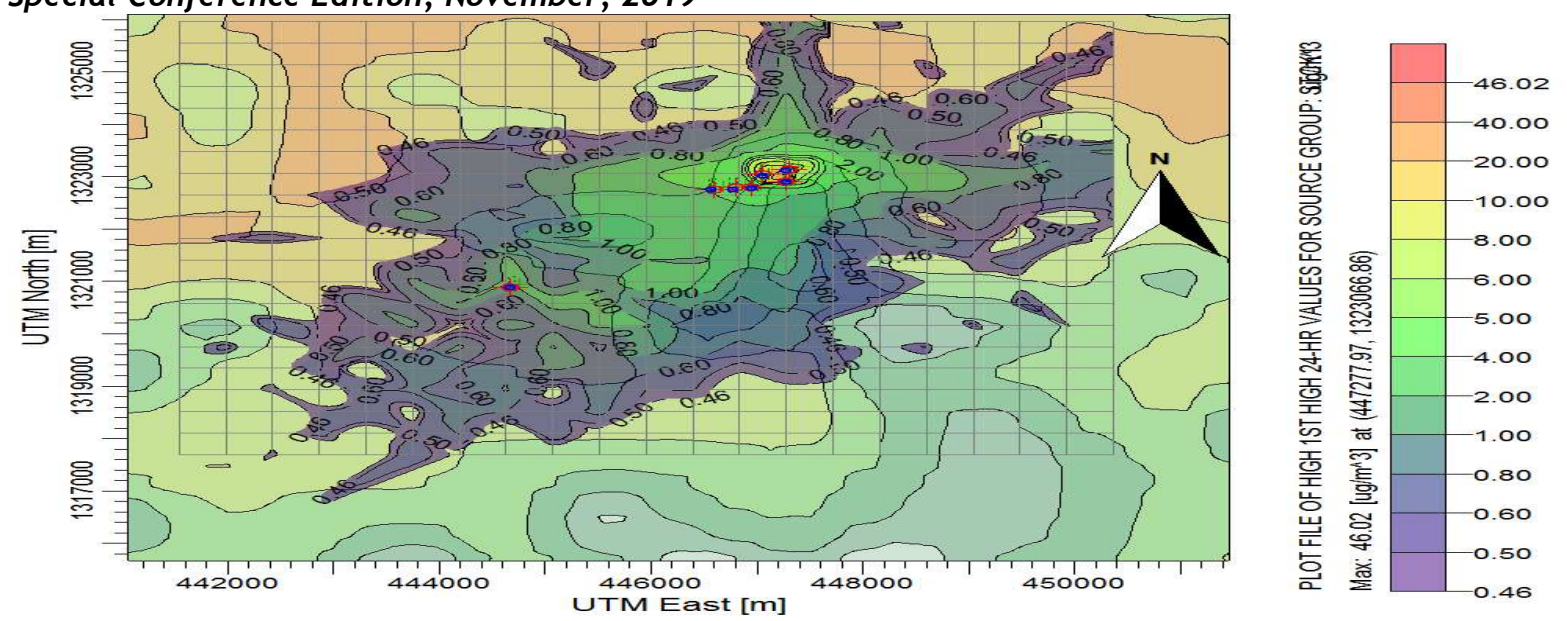

Figure 5b. AERMOD estimated surface concentration of stack 1 daily values of $\mathrm{NO}_{2}$ in Sharada domain

\section{CONCLUSION}

It was generally observed from the study that the predicted results were mostly lower than the experimentally measured ones. This is in agreement with findings of similar works of Abdel-Rahman, (2008), Dresser and Huizer (2011) and Langner and Klemm (2011). This can be attributed to the difficulties in obtaining actual meteorological variables in the sampling sites and the contributions of the concentration of the selected pollutants transporting around the domains studied as well as the mixing processes from other sources. Based on the result of the model evaluation, it was seen that AERMOD software could be used to estimate the surface concentrations of hourly $\mathrm{NO}_{2}$ with high accuracy at Sharada and Tokarawa domain which shows similar result with the work of Gibson et al. (2013) and $\mathrm{H}_{2} \mathrm{~S}$ concentration at Challawa and Tokarawa domain.

\section{REFERENCES}

Andre, J. C. and L. Mahrt, 1982: The nocturnal surface inversion and influence of clean-air radiative cooling. Journal Atmospheric Science, vol.39, Pp 864-878.

Briggs, G. A. (1973). Diffusion Estimation for Small Emissions. 1973 Annual Report, ATDL106, Air Resources Atmospheric Turbulene and Diffusion Laboratory, Environmental Res. Lab., NOAA, Oak Ridge, TN.

Brost, R. A., J. C. Wyngaard, and D. H. Lenschow, (1982) Marine stratocumulus layers: Part II: Turbulence budgets. Journal Atmospheric Science, vol.39, Pp 818-836

Caughey, S. J. and Palmer, S. G. (1979). Some aspects of turbulence structure through the depth of the convective boundary layer. Quart. J. Roy. Meteorology .Society, vol.105, Pp 811-827.

\section{Acknowledgements}

I would like to thank the university management for purchasing the AERMOD SOFTWARE to the department for the purpose of this work. Also, $i$ would like to express my gratitude to the head of the department and my supervisors (Prof. T. H. Darma and Prof. F. S. Koki) for their roles in soliciting the university support in purchasing the software.

In addition, my thanks go to the lakes environmental organisation for the $50 \%$ academic discount made during the purchase of the software and prof. B.I.Tijjani who received the software licence on behalf of the department.

Finally my special appreciations to $\operatorname{Dr}$ Aminu Sulaiman of the department of civil engineering and Prof. M.H.Ali for their helps in overcoming some of the problems and challenges associated with the software and all members of the department for their various advices to generally cope with difficulties of the entire research work.

Cimorelli,A.J.,Perry,S.G.,Venkatram,A.,Weil,J.C.,Pai ne,R.J.,Wilson,R.B.,Lee,R.F.,Peters,W.D.an d Paumier,J.O.(2003).AERMOD description of model formulation, U.S. Environmental protection Agency Report, PA 454/R-03002d,North Carolina,85pages.

Cimorelli, A.J., Perry, S.G., Venkatram, A., Weil, J.C., Paine,R.J.,Wilson, R.B., Lee, R.F., Peters, W.D. and Brode, R.W.(2005).AERMOD: a dispersion model for industrial source application part 1 general model formulation and boundary layer characterization. Journal of Applied Meteorology 44,682-693.

Demirarslan, K.O., Dogruparmak, S.C. and Karademir, A. (2017). Evaluation of three pollutant dispersion models for the environmental assessment of a district in Kocaeli, Turkey, Global NEST Journal, 19(1), 37-48. 
Special Conference Edition, November, 2019

Dresser, A.L. and Huizer, R.D. (2011).CALPUFF and AERMOD model validation study in the near field Martins Creek revisited. Journal of the Air \&Waste Management Association 61,647-659.

Dyer, A. J. (1974). A review of flux-profile relationships. Bound Layer Meteorology, vol.7, Pp 363-372.

Gibson, M.D., Heal, M.R., Li, Z., Kuchta, J., King, G.H.,Hayes, A. and Lambert, S.(2013).The spatial and seasonal variation of nitrogen dioxide and sulphur dioxide in cape Breton highland national park, Canada and the association with lichen abundance. Atmospheric Environment 64,303-311.

Hanna, S. R. and Paine, R. J. (1989). Hybrid Plume Dispersion Model (HPDM) development and evaluation. Journal of Applied Meteorological, vol. 28, Pp 206-224.

Hanna, S. R. and Chang, J. S. (1991).Modification of the Hybrid Plume Dispersion Model (HPDM) for urban conditions and its evaluation using the Indianapolis data set, Volume III: Analysis of urban boundary layer data. EPRI Project No. RP-02736-1, Electric Power Research Institute, Palo Alto, CA.

Haynes, P.H. (2010). Transport and Mixing of Atmospheric Pollutants. Department of Applied Mathematics and Theoretical Physics, Wilberforce Road, University of Cambridge, United Kingdom Lecture Notes Series.

Hicks, B. B. (1985). Behavior of turbulent statistics in the convective boundary layer. Journal Applied Meteorology vol.24, Pp 607-614.

Holtslag, A. A. M. and van Ulden, A. P. (1983).A simple scheme for daytime estimates for the surface fluxes from routine weather data. Climate Applied Meteorological. vol. 22, Pp 517-529.

Izumi, Y. (1971). Kansas 1968 Field Program Data Report. No. 379, AFCRL-72-0041, Air Force Cambridge Research Laboratory, Bedford, MA, Pp79.

Kaimal, J. C., Wyngaard, J. C., Haugen, D. A., Cote' O. R., Izumi, Y., Caughey, S. J. and Readings, C. J. (1976). Turbulence structure in the convective boundary layer. Journal Atmospheric Science, vol.33, Pp 2152-2169.

Lakes Environmental, (2018). AERMOD Model Formulation and Evaluation. http://www.weblakes.com /, accessed in November 2018.

Lawrence, K.D., Klimberg, R.K., and Lawrence, S.M. (2009). Fundamentals of forecasting using Excel industrial press, Inc. New York, ISBN 978-008311-3335-1.Pg 57-61

Ofoegbu, E.O., Fayemiyo, M.A and Omisore, M.O. (2014). Data Mining Industrial Air Pollution Data for Trend Analysis and Air Quality Index Assessment using a Novel Back-

End AQMS Application Software. International Journal of Innovation and Scientific Research. ISSN 2351-8014. Vol.11 No.2, PP: 237-247.

Ozkurt, N., Sari, D., Akalin, N. and Hilmioğlu, B. (2013), Evaluation of the impact of $\mathrm{SO}_{2}$ and $\mathrm{NO}_{2}$ emissions on the ambient airquality in the Çan-Bayramiç region of northwest Turkey during 2007-2008, Science of the Total Environment, 456457, 254-266.

Paine, R. J. and Kendall, S. B. (1993). Comparison of observed profiles of winds, temperature, and turbulence with theoretical results. Preprints, Joint conference of the American Meteorological Society and Air \& Waste Management Association Specialty Conference: The Role of Meteorology in Managing the Environment in the 90s, Scottsdale, AZ. Publication VIP-29, Air \& Waste Management Association, Pittsburgh, PA.

Panofsky, H. A. and Dutton, J. A. (1984). Atmospheric Turbulence: Models and Methods for Engineering Applications. John Wiley and Sons, New York, pp 417.

Panofsky, H. A., Tennekes, H., Lenschow, D. H., and Wyngaard, J. C. (1977).The characteristics of turbulent velocity components in the surface layer under convective conditions. Bound Layer Meteorology, vol. 11, Pp 355-361.

Stull, R. B. (1983).A heat flux history length scale for the nocturnal boundary layer. Tulles, vol. 35A, Pp 219-230.

Venkatram, A., Brode, R. Cimorelli, A., Lee, R., Paine, R., Perry, S., Peters, W., Weil, J. and Wilson, R. (2001). A complex terrain dispersion model for regulatory applications. Atmospheric Environment, 35, 4211-4221. 